\section{Planting-hole Amendments Modify Growth and Fruiting of Apples on Replant Sites}

\author{
G.H. Neilsen ${ }^{1}$, J. Beulah ${ }^{2}$, E.J. Hogue ${ }^{1}$, and R. Utkhede ${ }^{1}$ \\ Agriculture Canada Research Station, Summerland, BC VOH 1Z0, Canada
}

Additional index words. Malus domestics, monoammonium phosphate, mancozeb, peat, bacterial antagonist, replant disorder

\begin{abstract}
The effects of various nonfumigant planting-hole treatments on growth and yield of apple (Malus domestics Borkh.) trees were measured during the first 3 years after planting. Eight orchards diagnosed as having a replant problem were monitored. Firstyear shoot growth, the number of blossoms in the second year (inmost orchards), and firstyear trunk cross-sectional area increment (TCAI) in 50\% of test orchards were increased by monoammonium phosphate (MAP) fertilizer+ peat, MAP+ mancozeb, or MAP + peat + a bacterial antagonist. By the end of year 3, TCAI generally was not affected by treatments, but treatments resulted in more blossoms by the third season in two of seven orchards that blossomed in the second season. Cumulative yield after 3 years increased significantly in only three orchards, with the best treatment, MAP+ peat, resulting in cost recovery in only one orchard. Inadequate $\mathrm{K}$ or $\mathrm{Cu}$ nutrition may have reduced growth in some of the orchards, which were characterized by a wide range in yields, independent of planting-hole treatment.
\end{abstract}

Broad-spectrum soil sterilization has been used traditionally to mitigate orchard replant problems (Covey et al., 1984; Hoestra, 1968; Sewell and White, 1979) despite the cost and hazard of such treatment (Traquair, 1984). For example, multiyear growth improvements occurred in apples after soil fumigation with methyl bromide (Koch et al., 1980) or monoammonium phosphate (MAP) fertilization + soil disinfection with formalin $(37 \%$ aqueous solution of formaldehyde); tetrahydro3, 5 dimethyl-2H- 1, 3, 5,-thiadiazine-2-thione (dazomet); or Zn, Mn ethylene dithiocarbamate (mancozeb) (Neilsen and Yorston, 199 1). Recently, nonfumigant treatments, including the application of organic mixes within the planting hole, have increased first-year growth of apple on replant sites (Autio et al., 1991; Neilsen et al., 1991; Peryea and Covey, 1989), although only a few studies (Autio et al., 1991) have assessed the effects of these treatments beyond the first year.

Phosphorus fertilization in the planting year is recommended based on the growth response to $\mathrm{P}$ of apple seedlings on old orchard soils

Received for publication 1 Jan. 1993. Accepted for publication 6 Aug. 1993. Contribution no. 811 of Agriculture Canada, Research Station, Summerland, B.C. The late J. Yorston, British Columbia Ministry of Agriculture and Fisheries, was instrumental in obtaining funding for this project. We acknowledge the financial assistance of the Canada/British Columbia Subsidiary Agreement on Agri-Food Regional Development (ARDSA, 1989-90) and the British Columbia Fruit Growers Assn. The cost of publishing this paper was defrayed in part by the payment of page charges. Under postal regulations, this paper therefore must be hereby marked advertisement solely to indicate this fact.

'Reseach Scientist.

${ }^{2}$ Research Associate ARDSA project 11016.
(Slykhuis and Li, 1985). Increased flowering and fruit production in the second year is associated with first-year $\mathrm{P}$ applications (Neilsen et al., 1990). The longevity of these responses, however, has not been determined. Methods of improving the establishment and increasing the early fruiting of high-density orchards are important to achieve the early high production normally associated with such plantings (Neilsen and Yorston, 1991).

This study was initiated to assess the benefits of various nonfumigant planting-hole amendments to early apple tree growth and fruiting. The performance of high-density apple orchards on M.26 rootstock replanted into soils having a replant disorder was used to assess these treatments.

\section{Materials and Methods} were planted in late March to early Apr. 1988. A range of soil properties (Table 1) was measured from orchard to orchard, but all soils had varying degrees of apple replant disorder as indicated by a seedling bioassay (Neilsen et al., 1991).

'Summerland Red McIntosh'/M.26 was
${ }^{y}$ Detennined by loss on ignition at $450 \mathrm{C}$.
Eight apple orchard blocks (no. 68-75)

planted with the graft $\approx 4.5 \mathrm{~cm}$ above the soil surface in all orchards, except orchard 72, which contained 'Ace Red Delicious'/M.26. Five planting-hole treatments were arranged as randomized complete-block designs with five replications at each location. Each experimental unit was comprised of four-tree plots. Planting-hole volume varied among orchards and locations but was $\approx 100$ liters. The control (treatment 1) included $50 \mathrm{~g}$ of ammonium nitrate $(34 \mathrm{~N}-0 \mathrm{P}-0 \mathrm{~K})$. Treatments $2-5$ included 150 g MAP (11N-24P-0K). Mancozeb (Manzate 200; DuPont Canada, Mississauga, Ont.) at $30 \mathrm{~g}$ was applied in treatment 3 . The fertilizers and fungicide were incorporated uniformly into the soil that was returned to each planting hole. Treatments 4 and 5 included mixing 25 liters of peat with the soil that was to be returned to the planting hole but before applying MAP. For treatment 5, a crownrot antagonistic bacterium [Enterobacter aerogenes (Kruse) Honaeche and Edwards (B8)] was applied as a soil drench 1 week following planting and again in Sept. 1988. The antagonistic bacterium was cultured on Difco dextrose agar at $30 \mathrm{C}$ for $48 \mathrm{~h}$. The culture was removed from the petri dishes using a glass rod and suspended in distilled water. The bacterial suspension containing 1.6 $\times 10^{9}$ colony-forming units (cfu) was applied around the tree roots with 1 liter of water.

Postplanting management of the experimental blocks, including fertilization and insect and disease control, was performed according to commercial recommendations [British Columbia Ministry of Agriculture and Fisheries (BCMAF), 1989]. Irrigation systems included sprinklers on solid set (most orchards) or portable pipe (orchard 75) and trickle irrigation (orchards 70 and 71). Overall, orchard management was considered good to excellent and judged not to affect trees within orchards differentially.

Trunk diameters were measured $0.3 \mathrm{~m}$ above the graft union in Apr. 1988 and at the end of each growing season (Oct. 1988-90). Annual trunk cross-sectional area increment (TCAI) was calculated from these values. The number of blossom clusters was counted on data trees at bloom (late April to early May) in 1989 and 1990. The number of fruit set per tree was counted after June drop in 1989 and 1990.

From mid-July to early Aug. 1988-90, composite leaf samples of 30 leaves from the mid-third portion of new year's extension growth were obtained from each four-tree experimental plot. Leaf samples were oven-

Table 1. Selected chemical properties of soil samples collected from eight replanted apple orchards.

\begin{tabular}{lcccccccc}
\hline & \multicolumn{7}{c}{ Orchard } \\
\cline { 2 - 9 } Soil property (unit) & 68 & 69 & 70 & 71 & 72 & 73 & 74 & 75 \\
\hline $\mathrm{pH}(1$ soil : 2 water) & 6.9 & 7.5 & 6.5 & 6.8 & 8.0 & 7.3 & 6.5 & 7.0 \\
$\mathrm{P}\left(\mu \mathrm{g} \cdot \mathrm{m}^{-1}\right)^{z}$ & 43 & 16 & 77 & 18 & 44 & 23 & 86 & 37 \\
$\mathrm{~K}\left(\mu \mathrm{g} \cdot \mathrm{ml}^{-1}\right)^{z}$ & 221 & 133 & 214 & 369 & 188 & 75 & 436 & 159 \\
$\mathrm{Mg}\left(\mu \mathrm{g} \cdot \mathrm{m}^{-1}\right)^{z}$ & 122 & 129 & 220 & 792 & 256 & 114 & 439 & 78 \\
Organic matter $(\%)^{\mathrm{y}}$ & 2.4 & 1.0 & 3.0 & 4.8 & 3.5 & 1.2 & 4.7 & 1.1 \\
$\mathrm{Cu}\left(\mu \mathrm{g}^{-1} \mathrm{ml}^{-1}\right)^{\mathrm{x}}$ & 0.6 & 4.7 & 2.3 & 8.4 & 2.8 & 0.5 & 3.0 & 0.6
\end{tabular}

${ }^{2}$ As extracted with $0.25 \mathrm{~N}$ acetic acid and $0.015 \mathrm{~N} \mathrm{NH}_{4} \mathrm{~F}$ (Kelowna extractant).

${ }^{\mathrm{x}}$ As extracted with $0.005 \mathrm{MDTPA}, 0.01 \mathrm{M} \mathrm{CaC1}_{2}$, and $0.1 \mathrm{M}$ triethanolamine, with a $\mathrm{pH}$ of 7.3 
dried at $65 \mathrm{C}$ and ground in a stainless steel mill. Nitrogen and $\mathrm{P}$ concentrations were determined on a 0.25 -g sample after a Kjeldahl digestion (Association of Official Analytical Chemists, 1970). Other 1-g samples of the leaf powder were dry-ashed at $475 \mathrm{C}$ and dissolved in $0.5 \mathrm{M} \mathrm{HCl}$ before determining $\mathrm{Ca}, \mathrm{Mg}, \mathrm{K}$, $\mathrm{Zn}, \mathrm{Mn}, \mathrm{Fe}$, and $\mathrm{Cu}$ concentrations by atomic absorption spectrophotometry. The calorimetric and spectrophotometric methods have previously been described by Neilsen and Yorston (1991).

Analysis of variance was performed for TCAI and for blossom and fruit counts as a split-split plot- the eight orchards were main plot units; the five planting-hole treatments, replicated five times, were subplots; and years were sub-subplots. TCAI was measured for 3 years, and blossom and fruit counts were taken for 2 years. Cumulative 3-year yield was analyzed as a split plot with orchards as main plots and treatments as subplots.

\section{Results and Discussion}

A pooled analysis of variance for the 3 years showed highly significant year $\times$ treatment $x$ site, year $x$ treatment, and year $\times$ site interactions for cumulative TCAI and blossom and fruit counts (Table 2). The importance of site and year was an expected consequence of monitoring the growth and fruiting of orchards located on a wide range of soils with varying replant seventy and over a period of time representing the transition from vegetative to reproductive growth. A significant treatment $\mathrm{x}$ site interaction was observed only for fruit count, which was a consequence of inconsistent fruit thinning and erratic cropping among orchards in the second year. Therefore, our discussion focuses on cumulative rather than annual yield.

Over the first 3 years at all sites, the best planting-hole treatment was MAP + peat. The effect of this treatment, however, was not significantly different than MAP + mancozeb, which was not significantly different from the control. Cumulative TCAI at the end of the first and third years was illustrative of the effects of treatment, site, and year (Table 3). At the end of the first growing season, TCAI was greater for planting-hole treatments in four of the eight orchards. Improved vigor generally was observed in orchards with poorest overall growth. Growth was increased when first-year TCAI of control trees was $<0.7 \mathrm{~cm}^{2}$. The best planting-hole treatment differed from orchard to orchard. MAP + mancozeb was associated with the best growth in orchards 68 , 72 , and 75 , although MAP + peat was among the best in orchards 72,73 , and 75 and better than control treatments in orchard 68. Adding a bacterial antagonist to peat + MAP did not increase first-year TCAI relative to that achieved by peat + MAP alone, and in orchard 75 , it did not increase TCAI relative to control trees. Only in orchard 68 did MAP alone increase TCAI relative to control trees. Increases in first-year total shoot growth as a consequence of most of these planting-hole treatments were observed previously in all

Table 2. Pooled analyses of variance for years, various planting-hole treatments, and eight apple orchard sites on cumulative annual trunk cross-sectional area increment (TCAI), number of blossoms and fruit.

\begin{tabular}{|c|c|c|c|c|c|c|c|c|c|}
\hline \multirow[b]{2}{*}{ Source } & \multicolumn{3}{|c|}{ Cumulative TCAI } & \multicolumn{3}{|c|}{ Blossom count } & \multicolumn{3}{|c|}{ Fruit count } \\
\hline & $\mathrm{df}$ & $F$ value & $P>\mathrm{F}$ & $\mathrm{df}$ & F value & $P>\mathrm{F}$ & df & F value & $P>\mathrm{F}$ \\
\hline Sites $(S)$ & 7 & 49.80 & 0.0001 & 7 & 35.58 & 0.0001 & 7 & 215.88 & 0.0001 \\
\hline Error A [R(S)] & 32 & 8.80 & 0.0001 & 32 & 3.95 & 0.0001 & 32 & 4.11 & 0.0001 \\
\hline Treatment (T) & 4 & 4.89 & 0.0011 & 4 & 9.05 . & 0.0001 & 4 & 4.23 & 0.0030 \\
\hline $\mathrm{S} \times \mathrm{T}$ & 28 & 1.46 & 0.0822 & 28 & 1.08 & 0.3773 & 28 & 1.85 & 0.0114 \\
\hline Error $B[R \times T(S)]$ & 127 & 3.51 & 0.0001 & 127 & 1.45 & 0.0195 & 128 & 1.75 & 0.0001 \\
\hline Year $(\mathrm{Y})$ & 2 & 1485.12 & 0.0001 & 1 & 287.49 & 0.0001 & 1 & 704.87 & 0.0001 \\
\hline $\mathrm{Y} \times \mathrm{S}$ & 14 & 36.71 & 0.0001 & 7 & 18.80 & 0.0001 & 7 & 39.52 & 0.0001 \\
\hline Error $\mathrm{C}[\mathrm{Y} \times \mathrm{R}(\mathrm{S})]$ & 64 & 2.03 & 0.0001 & 32 & 3.51 & 0.0001 & 32 & 3.13 & 0.0001 \\
\hline $\mathrm{Y} \times \mathrm{T}$ & 8 & 3.23 & 0.0016 & 4 & 29.34 & 0.0001 & 4 & 7.89 & 0.0001 \\
\hline $\mathrm{Y} \times \mathrm{T} \times \mathrm{S}$ & 56 & 1.74 & 0.0022 & 28 & 7.02 & 0.0001 & 28 & 5.69 & 0.0001 \\
\hline Residual [Y $\times \mathbf{T} \times \mathrm{R}(\mathrm{S})]$ & 254 & -- & --- & 127 & -- & --- & 127 & -- & -. \\
\hline
\end{tabular}

${ }^{2}$ Analysis of variance conducted as a split-split plot where site is main plot, planting-hole treatment is subplot, and year is sub-sub-plot.

eight of these orchards (Neilsen et al., 1991); trunk growth was increased less frequently by these planting-hole treatments.

By the end of the third growing season, TCAI was significantly affected by the planting-hole treatments only in orchard 75 (Table 3 ). Here trees given MAP or MAP + peat + bacterial antagonist grew less than trees grown under control or other treatments. The cumulative evidence therefore suggests that the planting-hole treatments tested in this study had little or no effect on tree vigor after 3 years. Although no long-term tree-growth increments were reported in this study, increased vigor beyond the third growing season has been achieved in replant situations after methyl bromide fumigation (Koch et al., 1980) or formalin + MAP application (Neilsen and Yorston, 1991).

Blossom count increased relative to control or MAP treatments over all orchards in the first two flowering years after applying $\mathrm{MAP}+$ mancozeb, MAP + peat, or MAP + peat + bacterial antagonist to the planting hole. The greatest treatment effect occurred in the first flowering year, with significant effects observed in all orchards (Table 4). Trees in orchard 72 did not flower until year 3 , but significant effects were measured in their first flowering year (B3). Initial blossom production was greater for treatments involving combinations of MAP+ peat, MAP + mancozeb, or MAP + peat + bacterial antagonist, with the effects of these treatments differing somewhat but not consistently among orchards. MAP + mancozeb was superior for blossom stimulation in orchards 68, 70, and 71. Peat + MAP and peat + MAP+ bacterial antagonist led to blossom counts similar to those of control trees in orchards 70 and 75, respectively. Applying MAP to the planting hole generally had an intermediate effect on blossoming, with firstyear blossom counts exceeding the control tree values only in orchards 68,71 , and 73 . Improved blossoming of apple trees has previously been associated with first-year $P$ fertilization and increased root growth (Neilsen et al., 1990). From this study, we conclude that the combination of MAP fertilization with treatments that apparently stimulate initial root growth increase flower initiation.

Treatment effects, however, diminished in the second flowering year (year 3, B3), with the number of blossoms produced significantly affected by planting-hole treatments in only three of the seven orchards that bloomed in both years (Table 4). In orchard 73, the number of blossoms increased more than the control trees for all treatments. In orchard 75, the MAP + peat treatment resulted in the highest

Table 3. Mean trunk cross-sectional area increment (TCAI) at a $0.3-\mathrm{m}$ height in apple orchards where significant differences were measured, 1 and 3 years after planting. ${ }^{2}$

\begin{tabular}{|c|c|c|c|c|c|c|c|c|}
\hline \multirow{4}{*}{$\begin{array}{l}\text { Planting-hole } \\
\text { soil treatment }\end{array}$} & \multicolumn{8}{|c|}{ TCAI $\left(\mathrm{cm}^{2}\right)$} \\
\hline & \multicolumn{8}{|c|}{ Orchard no. } \\
\hline & \multicolumn{2}{|c|}{68} & \multicolumn{2}{|c|}{72} & \multicolumn{2}{|c|}{73} & \multicolumn{2}{|c|}{75} \\
\hline & Yr 1 & Yr 3 & Yr 1 & Yr 3 & Yr 1 & Yr 3 & Yr 1 & Yr 3 \\
\hline Control $^{y}$ & $0.4 \mathrm{c}$ & 3.4 & $0.4 \mathrm{~b}$ & 4.6 & $0.5 \mathrm{c}$ & 2.7 & $0.6 \mathrm{~b}$ & $\overline{6.5 \mathrm{a}}$ \\
\hline $150 \mathrm{~g} \mathrm{MAP}^{\mathrm{x}}$ & $0.7 \mathrm{~b}$ & 3.5 & $0.4 \mathrm{~b}$ & 3.9 & $0.7 \mathrm{bc}$ & 2.2 & $0.5 b$ & $4.3 \mathrm{~b}$ \\
\hline 150g MAP+ & $10 a$ & 35 & 06 a & 5.1 & $06 \mathrm{C}$ & 28 & 09 a & $71 \mathrm{a}$ \\
\hline $150 \mathrm{~g} \mathrm{MAP+}$ & $1.0 \mathrm{a}$ & 3.5 & $0.0 \mathrm{a}$ & 5.1 & $0.0 \mathrm{C}$ & 2.8 & $0.9 \mathrm{a}$ & $1.1 \mathrm{a}$ \\
\hline $\begin{array}{l}25 \text { liters peat } \\
150 \mathrm{~g} \mathrm{MAP+}\end{array}$ & $0.7 \mathrm{~b}$ & 3.5 & $0.6 \mathrm{a}$ & 5.1 & $1.0 \mathrm{a}$ & 2.8 & $0.9 \mathrm{a}$ & $7.3 \mathrm{a}$ \\
\hline $\begin{array}{l}25 \text { liters peat+ } \\
\text { bacterial antagonist } \\
\text { Significance }\end{array}$ & $0.9 \mathrm{ab}$ & $\begin{array}{l}4.2 \\
\text { NS }\end{array}$ & $\underset{*}{0.6} \mathrm{a}$ & $\begin{array}{l}5.3 \\
\mathrm{NS}\end{array}$ & $\underset{* *}{0.9} \mathrm{ab}$ & $\begin{array}{l}2,5 \\
\text { NS }\end{array}$ & $\underset{* *}{0.6 \mathrm{~b}}$ & $\begin{array}{r}4.0 \mathrm{~b} \\
* * * * *\end{array}$ \\
\hline
\end{tabular}

Data presented are the means of 20 observations. Mean separation in columns by Duncan's multiple range test.

${ }^{y}$ Control was $50 \mathrm{~g} \mathrm{NH}_{4} \mathrm{NO}_{3}$.

${ }^{x} \mathrm{MAP}=$ monoammonium phosphate

$*,{ }^{*},{ }^{*} * * *{ }^{\mathrm{Ns}}$ Significant at $P \leq 0.05,0.01$, or 0.0001 , or nonsignificant, respectively. 


\section{Soil Management, Fertilization, \& Irrigation}

Table 4. Mean number of blossom clusters in the second (B2) and third (B3) growing seasons and cumulative fruit count (F3) for various planting-hole soil treatments in eight different replanted orchards. ${ }^{2}$

\begin{tabular}{|c|c|c|c|c|c|c|c|c|c|c|c|c|c|c|c|c|c|c|c|c|c|c|c|}
\hline \multirow[b]{3}{*}{ Planting-hole treatment } & \multicolumn{23}{|c|}{ Orchard no. } \\
\hline & \multicolumn{3}{|c|}{68} & \multicolumn{3}{|c|}{69} & \multicolumn{3}{|c|}{70} & \multicolumn{3}{|c|}{71} & \multicolumn{2}{|c|}{$72^{y}$} & \multicolumn{3}{|c|}{73} & \multicolumn{3}{|c|}{74} & \multicolumn{3}{|c|}{75} \\
\hline & $\mathrm{B} 2$ & B3 & F3 & B2 & B3 & F3 & $\mathrm{B} 2$ & B3 & $\mathrm{F} 3$ & B2 & B3 & F3 & B3 & F3 & B2 & B3 & $\mathrm{F} 3$ & $\mathrm{~B} 2$ & B3 & $\mathrm{F} 3$ & $\mathrm{~B} 2$ & B3 & F3 \\
\hline Control ${ }^{x}$ & $4 \mathrm{c}$ & 119 & $10 \mathrm{c}$ & $9 \mathrm{~b}$ & 95 & 32 & $4 \mathrm{c}$ & $77 \mathrm{a}$ & 39 & $20 \mathrm{~d}$ & $153 a$ & 110 & $8 \mathrm{c}$ & 0.3 & $0.7 \mathrm{c}$ & $26 c$ & 15 & $3 c$ & 139 & $42 \mathrm{~b}$ & $16 \mathrm{bc}$ & $80 b c$ & $19 \mathrm{bc}$ \\
\hline $150 \mathrm{~g} \mathrm{MAP}^{*}$ & $15 \mathrm{~b}$ & 115 & $12 \mathrm{bc}$ & $33 \mathrm{ab}$ & 78 & 35 & $22 \mathrm{c}$ & $47 a b$ & 33 & $58 \mathrm{c}$ & $109 \mathrm{~b}$ & 115 & $11 \mathrm{bc}$ & 0.4 & $14 b$ & $42 \mathrm{~b}$ & 20 & $18 \mathrm{bc}$ & 100 & $44 \mathrm{~b}$ & $11 \mathrm{c}$ & $52 \mathrm{c}$ & $16 \mathrm{c}$ \\
\hline \multicolumn{24}{|l|}{$150 \mathrm{~g} M A P+$} \\
\hline $30 \mathrm{~g}$ mancozeb & $27 a$ & 122 & $11 \mathrm{bc}$ & $53 \mathrm{a}$ & 94 & 36 & 67 a & $17 \mathrm{~d}$ & 24 & $129 \mathrm{a}$ & $84 \mathrm{~b}$ & 128 & $21 \mathrm{a}$ & 0.7 & $30 \mathrm{a}$ & $48 \mathrm{ab}$ & 21 & $44 \mathrm{a}$ & 130 & $51 \mathrm{~b}$ & $18 \mathrm{ab}$ & $90 \mathrm{ab}$ & $26 \mathrm{ab}$ \\
\hline \multicolumn{24}{|l|}{$150 \mathrm{~g} \mathrm{MAP}+$} \\
\hline 25 liters peat & $16 \mathrm{~b}$ & 114 & $13 \mathrm{abc}$ & $43 \mathrm{a}$ & 89 & 37 & $20 \mathrm{c}$ & $73 \mathbf{a}$ & 40 & $90 \mathrm{bc}$ & $101 \mathrm{~b}$ & 129 & $19 \mathrm{ab}$ & 0.1 & 34 a & 59 a & 22 & $28 a b$ & 115 & $54 \mathrm{ab}$ & 23 a & $109 \mathrm{a}$ & $30 \mathrm{a}$ \\
\hline \multicolumn{24}{|l|}{$\begin{array}{l}150 \text { g MAP + } \\
25 \text { liters perat }+\end{array}$} \\
\hline bacterial antagonist & $17 \mathrm{~b}$ & 136 & 15 a & $52 \mathrm{a}$ & 73 & 32 & $49 \mathrm{~b}$ & $31 \mathrm{~cd}$ & 30 & $93 \mathrm{~b}$ & $94 \mathrm{~b}$ & 120 & $18 a b$ & 0.5 & 39 a & $45 \mathrm{~b}$ & 19 & $31 \mathrm{ab}$ & 119 & $65 \mathrm{a}$ & $13 b c$ & $68 \mathrm{bc}$ & $19 \mathrm{bc}$ \\
\hline Significance & $* * * *$ & NS & $*$ & $*$ & NS & NS & $* * * *$ & NS & NS & $* * * * *$ & * & NS & $*$ & NS & $*$ ***** & ** & NS & $* *$ & NS & $* *$ & $* *$ & $* *$ & ** \\
\hline
\end{tabular}

${ }^{\bar{T}}$ Data presented are the means of 20 operations. Mean separation in columns by Duncan's multiple range test.

${ }^{y}$ Fruiting commenced in third year.

${ }^{x}$ Control was $50 \mathrm{~g} \mathrm{NH}_{4} \mathrm{NO}_{3}$.

"MAP = monoammonium phosphate.

$*, * *, * * * *$ Significant at $P<0.05,0.01$, or 0.0001 , or nonsignificant, respectively.

blossom counts. Furthermore, orchard 71 produced the most blossoms on control trees. Although early flowering can be stimulated by planting-hole treatments, care must be taken to avoid overcropping and thus ensure return flowering.

There was a significant treatment $\mathrm{x}$ site interaction for cumulative yield (F3, Table 4). Higher cumulative yield was associated with planting-hole treatments only in orchards 68 , 74 , and 75. In these orchards, MAP+ peat was one of the best overall treatments. At the time of planting, the cost of materials for the peat+ MAP treatment was about Can. $\$ 1.20$ per planting hole. An additional nineteen 150-g apples per tree sold at $\$ 0.44 / \mathrm{kg}$ would have been required to recoup the cost. Costs would have been recovered only in orchard 71 by the third year for this treatment. MAP + peat produced more fruit per tree relative to control in all but orchard 72 ('Delicious'), where frutiting was negligible by year 3 . Planting-hole treatments involving peat + MAP generally were useful. for initiating fruiting, although their economic advantage over the first three growing seasons was marginal and not as pronounced as benefits reported for treatments involving broad-spectrum fumigation of a larger soil volume in the planting-hole area (Hoestra, 1968; Koch et al., 1980). Furthermore, maximum yield potential was reduced considerably in many orchards despite the planting-hole treatments, as indicated by a greater than 10-fold range [10 (orchard 68) to 110 (orchard 71)] in control-treatment cumulative fruit count for the same cultivar-rootstock combination.

During the first three growing seasons for all treatments, leaf $\mathrm{N}, \mathrm{P}, \mathrm{K}, \mathrm{Ca}, \mathrm{Fe}$, and $\mathrm{Mn}$ concentrations were in the expected range for normal growth and production (Shear and Faust, 1980; data not shown); however, leaf $\mathrm{Zn}$ concentrations were high, an indication of widespread foliar application of $\mathrm{Zn}$. Also, in the two orchards (69 and 73) with the lowest K concentrations and poorer than average growth over 3 years, leaf $\mathrm{K}$ was $<1.2 \%$ in the first fruiting year and possibly deficient. These orchards had the lowest extractable soil $\mathrm{K}$ values (Table 1), suggesting that inadequate $K$ supply accounted for some of the wide variation in tree performance from orchard to orchard. Lower than recommended leaf $\mathrm{Mg}$ was observed in orchards 68,70 , and 75 , which had the lowest extractable soil $\mathrm{Mg}$ concentration. Orchards 70 and 75, however, had above average growth rates (Table 2), implying that low leaf $\mathrm{Mg}$ concentrations had little effect on tree vigor. Similar conclusions were reached for 'Cox Orange Pippin' apple over a $0.07 \%$ to $0.33 \%$, range of leaf $\mathrm{Mg}$ (Bould and Parfitt, 1973). Possible $\mathrm{Cu}$ deficiencies were indicated in orchards 68,74 , and 75 , where leaf concentrations were frequently $<4 \mu \mathrm{g} \cdot \mathrm{g}^{-1}$ and where extractable soil $\mathrm{Cu}$ values (except in orchard 74) were $<1.0 \mu \mathrm{g} \cdot \mathrm{g}^{-1}$ (Table 1). A range in tree vigor and yield, however, was measured among these orchards, an indication that $\mathrm{Cu}$ deficiency was not a definitive cause of the variation in performance from orchard to orchard.

In summary, planting-time treatments involving amendment of the planting-hole environment consistently increased first- year shoot growth and the number of blossom clusters in the second growing season. First-year TCAI was increased in $50 \%$ of the test orchards, but by the third year, a significant negative effect was measured in one of the orchards. Increases in blossom count in the third growing season, associated with planting-hole amendments, were measured in two of the seven orchards that blossomed in the second and third year. Furthermore, by the third year, the range in vigor and yield among orchards exceeded the growth benefits associated with treatments. As a consequence, the performance of the best planting-hole treatment, MAP + peat, resulted in cost recovery by the end of the third year in only one orchard. Inadequate $\mathrm{K}$ and $\mathrm{Cu}$ nutrition may have affected growth in some orchards and may have contributed to some of the variation in growth among orchards.

\section{Literature Cited}

Association of Official Analytical Chemists. 1970 Official methods of analysis. Assn. Offic. Agr. Chem., Washington, D.C.

Autio, W. R., D.W. Greene, D.R. Cooley, and J.R. Schupp. 1991. Improving the growth of newly planted apple trees. HortScience 26:840-843.

Bould, C. and R.L Parfitt. 1973. Leaf analysis as a guide to the nutrition of fruit crops. X. Magnesium and phosphorus sand culture experiments with apple. J. Sci. Food Agr. 24: 175-185.

British Columbia Ministry of Agriculture and Fisheries. 1989. Tree fruit production guide for interior districts for commercial growers. CountryLife, Surrey, B.C.

Covey, R.P., B.L. Koch, and W.A. Haglund. 1984 Control of apple replant disease with formaldehyde in Washington. Plant Dis. 68:981-983.

Hoestra, H. 1968. Replant disease of apple in the Netherlands. Mededelingen Lanbouwhogeschool Wageningen 68-13.

Koch, B. L., R.P. Covey, Jr., and W. Haglund. 1980. Effect of soil fumigation on the early growth and production of 'Delicious' apple trees. J. Amer. Soc. Hort. Sci. 105:887-890.

Neilsen, G.H.J. Beulah, E.J. Hogue, and R.S. Utkhede. 1991. Use of greenhouse seedling bioassays to predict first year growth of apple trees planted in old orchard soil. HortScience 26: 1383-1 386.

Neilsen, G. H., E.J. Hogue, and P. Parchomchuk. 1990. Flowering of apple trees in the second year is increased by first-year P fertilization. HortScience 25: 1247-1250,

Neilsen, G.H. and J. Yorston. 1991. Soil disinfection and monoammonium phosphate fertilization increase precocity of apples on replant problem soils. J. Amer. Soc. Hort. Sci. 116:651-654.

Peryea, F. and R.P. Covey. 1989. Replant management strategies influence early growth of apple trees in a sand soil. HortScience 24:947-949.

Sewell, G.W.F. and G.C. White. 1979. The effects of formafin and other soil treatments on the replant disease of apple. J. Hort. Sci. 54:333-335.

Shear, C.B. and M. Faust. 1980. Nutritional ranges in deciduous tree fruits and nuts. Hort. Rev. 2142-163.

Slykhuis, J.T. and T.S.C. Li. 1985. Responses of apple seedlings to biocides and phosphate fertilizers in orchard soils in British Columbia. Can. J. Plant Pathol. 7:294-301.

Traquair, J.A. 1984. Etiology and control of orchard replant problems: A review. Can. J. Plant Pathol. 6:54-52. 